\title{
Physical and Mechanical Properties Evaluation of Corncob and Sawdust Cement Bonded Ceiling Boards
}

\author{
Atoyebi Olumoyewa Dotun ${ }^{1 a^{*}}$, Odeyemi Samson Olalekan ${ }^{2 b}$, \\ Azeez Lateef Olugbenga ${ }^{3 c}$, Modupe Abayomi Emmanuel ${ }^{1 \mathrm{~d}}$ \\ ${ }^{1}$ Civil Engineering Department, Landmark University, Omu-Aran, Kwara State, Nigeria \\ ${ }^{2}$ Department of Civil Engineering, Kwara State University, Malete, Kwara State, Nigeria \\ ${ }^{3}$ Department of Civil Engineering, Ladoke Akintola University of Technology, Ogbomoso, \\ Oyo State, Nigeria \\ aatoyebi.olumoyewa@Imu.edu.ng, bsamson.odeyemi@kwasu.edu.ng, lastruct@gmail.com, \\ cmodupe.abayomi@Imu.edu.ng.
}

\section{Keywords: Corncob, Sawdust, Cement, Ceiling Board, Agricultural Waste}

\begin{abstract}
This study considered the production of composite ceiling boards from both agricultural and industrial wastes. Boards with different blending proportions by weight of cement, corncob and sawdust (Cem:Ccb:Swd) were produced and tested. Physical and mechanical tests such as Water Absorption (WA), Thickness Swelling (TS), Modulus of Elasticity (MOE) and Modulus of Rupture (MOR) were carried out on the products. The findings revealed that the board with Cem:Ccb:Swd blending proportion 50:10:40 gave the highest values of MOE and MOR and also had the lowest values of WA and TS. The MOE and MOR values of $9351.48 \mathrm{~N} / \mathrm{mm}^{2}$ and $3.432 \mathrm{~N} / \mathrm{mm}^{2}$ are both higher than the minimum values of $550 \mathrm{~N} / \mathrm{mm}^{2}$ and $3 \mathrm{~N} / \mathrm{mm}^{2}$ specified for MOE and MOR respectively by the American National Standard Institute, for general-use particle boards. The cement content is inversely proportional to the physical properties and directly proportional to the mechanical properties.
\end{abstract}

\section{Introduction}

Human civilization has advanced so much that its effect on construction has created the emergence of the development of new construction materials. In the construction of buildings, construction cost is influenced greatly by factors like cost of materials and the nature of materials being used. The use of various alternative materials has gained priority due to the increase in demand on construction to solve basic needs of standard living in the environment. The utilization of locally made raw materials is of great importance and concern for all developing countries including Nigeria, and its importance to the local material industries has been widely acknowledged and emphasized. The ever-increasing housing demand has given rise to the need to source for construction materials like bricks, cement, aggregates, steel, aluminum, wood, cladding and partitioning materials [1-3]. Different agricultural products and wastes such as corn cob, corn stalk, coconut fibers, rice husks, rice, bagasse, cereal, palm leaves oil, bamboo, straw, palm kernel, cotton stalks, kenaf, sunflower hulls and stalks, banana stalks, durian peel among others have been investigated by several authors [4-13] for the production of innovations like particleboards, hardboards and fiber boards, with emphasis on their thermal insulation capabilities. Furthermore there are studies on how residues such as newspaper [14], honeycomb [15] or polymeric wastes [16] can be used in the processing of different building components. There are also various research efforts on the use of corn cob ash (CCA) as a pozzolan in blended cement concrete [17-19], some other waste products which possess pozzolanic properties that have been researched into for use in blended cement are rice husk ash, sawdust ash, waste burnt clay [2, 20-22]. The term ceiling refers to the upper part of the interior surface of a room which covers the suspended floor above or the roof. It accounts for less than $2 \%$ of the total cost of construction of small residential buildings such as blocks of flats [23]. Various researchers have worked on the production of ceiling boards from different agro-wastes like poplar (Populus deltoides) chopped 
strands, lignocellulosic wastes, strawboard \& corncob [24-27] as a way of getting substitutes for the various types of conventional ceiling materials available especially asbestos. Medically, the use of asbestos is subjected to severe safety restrictions due to the fine dust or fibers produced when working with it, causing lung diseases [26]. Cement Bonded boards have great fire and sound resistant properties. They have higher moisture resistance than other types of particle boards and are used in the construction industry to form roofing and wall covering in high-humidity areas. Cement bonded boards are of high durability and versatility, useful in rough external conditions and have a high resistance to brown-rot and white-rot fungi. Corncob, the most important cereal crop in sub-Saharan Africa is the central part of maize. According to Food and Agriculture Organization (FAO) data, it was estimated that in 2012, 875 million tons of maize were produced worldwide [28]. The United States with $31 \%$ of the world production was the largest producer of maize with China (24\%) and Brazil (8\%) taking the second and third positions respectively. The largest producer in Africa being South Africa (10th position in the world) with the highest production of 12 million tons and Nigeria (14th position in the world) was the second largest producer of maize in Africa. Thus, this statistic reveals that there is high abundance of corncob that can serve as raw material for the production of ceiling boards in this study. Sawdust, a by-product of lumber and wood industries is small particle of wood generated from the processing of timber. Sawdust, also known as wood chips is collected basically from the endocarp of timber logs and timber defects. This process is a daily activity that causes heaps of sawdust to be generated after each day. This study investigates the use of corncob and sawdust as a composite material in ceiling board production and determines the best blending proportion that gives the finest board. It covers comprehensive experimental laboratory investigations on the ceiling boards produced from the mixture of corncob and sawdust as replacement for other conventional materials being used.

\section{Materials and Methods}

Materials: The materials used for this research were Corncob, Sawdust, Ordinary Portland Cement (OPC, Grade 42.5), Water and Calcium Chloride $\left(\mathrm{CaCl}_{2}\right)$. Calcium chloride $\left(\mathrm{CaCl}_{2}\right)$ which was the additive served as a mineralizing agent to quicken the setting of the cement.

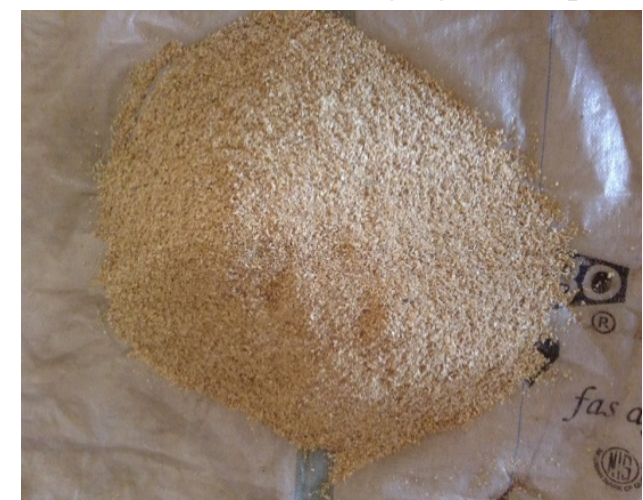

Fig. 1 Corn Cob after grinding

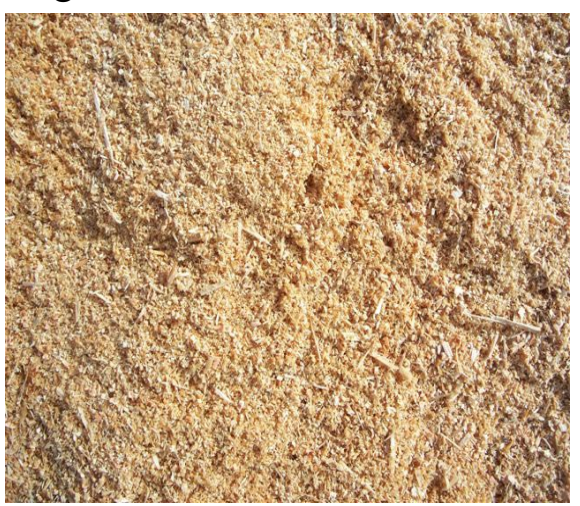

Fig. 2 Sawdust Sample

Experimental Procedure: The corncob utilized for this study were collected and broken into maximum $4 \mathrm{~mm}$ particle sizes with the hammer milling machine. The resulting chips of corncobs were air dried for 2 weeks before being treated with hot water at a temperature of $85^{\circ} \mathrm{C}$. This pretreatment was also carried out for the sawdust in order to ensure the proper removal of the undesirable water soluble chemical substances like phenolic compounds, oil extracts and starch which may likely inhibit the setting of the cement used as the binder for board formation. The pretreated sawdust and chip of corncobs were then air dried again to moisture content (M.C) of $12 \%$ before further use.

The weights of all the materials were varied to produce nine different board samples as determined by the board mix ratio. The quantity of chemical additive used was based on the percentage weight of the chemical in relation to the weight of cement. The amount of water was calculated using Eq. 1 
and weighed in a cylinder; each of the materials (cement, corncob and sawdust) calculated were put in polythene bags.

$$
\text { Amount of Water }=0.60 C+(0.30-M C)
$$

Where $\mathrm{C}=$ Cement weight, $\mathrm{W}=$ Weight of Corncob + Sawdust, $\mathrm{MC}=$ Moisture Content

The weights required to produce the Cement Bonded Board (CBB) from corncob and sawdust is as shown in Table 1.

Some other factors that are constant and used in this research are as follows:
(a) Additive concentration $\left(\mathrm{CaCl}_{2}\right)=3 \%$ of cement weight
(b) Board thickness $=10 \mathrm{~mm}$
(c) Moisture content $=12 \%$
(d) $\quad$ Board size $=350 \mathrm{~mm} \times 350 \mathrm{~mm} \times 10 \mathrm{~mm}$
(e) Pressing pressure $=1.23 \mathrm{~N} / \mathrm{mm}^{2}$

Table 1 Weights required to produce Cement Bonded Board

\begin{tabular}{cccccc}
\hline $\begin{array}{c}\text { Materials } \\
\text { Proportion } \\
\text { Cem:Ccb:Swd (\%) }\end{array}$ & $\begin{array}{c}\text { Weight of } \\
\text { Cement }(\mathrm{g})\end{array}$ & $\begin{array}{c}\text { Weight of } \\
\text { Corncob } \\
(\mathrm{g})\end{array}$ & $\begin{array}{c}\text { Weight of } \\
\text { Sawdust } \\
(\mathrm{g})\end{array}$ & $\begin{array}{c}\text { Weight of } \\
\text { Additive } \\
(\mathrm{g})\end{array}$ & $\begin{array}{c}\text { Weight of } \\
\text { Water }(\mathrm{g})\end{array}$ \\
\hline 40:40:20 & 588 & 588 & 294 & 17.6 & 511.6 \\
40:30:30 & 588 & 441 & 441 & 17.6 & 511.6 \\
40:20:40 & 588 & 294 & 588 & 17.6 & 511.6 \\
$50: 10: 40$ & 735 & 147 & 588 & 22.1 & 573.3 \\
$50: 20: 30$ & 735 & 294 & 441 & 22.1 & 573.3 \\
$50: 25: 25$ & 735 & 367.5 & 367.5 & 22.1 & 573.3 \\
$60: 20: 20$ & 882 & 294 & 294 & 26.5 & 635 \\
$60: 30: 10$ & 882 & 441 & 147 & 26.5 & 635 \\
$60: 10: 30$ & 882 & 147 & 441 & 26.5 & 635 \\
\hline
\end{tabular}

The quantities of cement, sawdust and corncob were measured out into an aluminum bowl. The required quantity of additive was dissolved in the quantity of water needed and mixed together thoroughly. The water containing chemical additive i.e. calcium chloride $\left(\mathrm{CaCl}_{2}\right)$ was then added to the bowl containing cement, corncob and sawdust and evenly mixed together to result into a mix free of lumps.

Board Formation. A uniform size $350 \mathrm{~mm}$ x $350 \mathrm{~mm}$ of the board was placed on a caul plate made of iron which was covered with polythene sheets to separate the board from the plate. Pre-pressing was carried out on the formed mat to ease loading on the cold press and to reduce the thickness; this was done using a wooden caul plate. After the pre-pressing, the boards placed on the metal caul plate was transferred to the hydraulic jack as shown in fig. 3 where it stayed for 24 hours under an applied pressure of $1.23 \mathrm{~N} / \mathrm{mm}^{2}$.

Curing Process. After pressing, the compressed mat was released, the boards were demoulded and wrapped with polythene sheet (fig. 4) for 28 days in the laboratory environment to prevent possible loss of water and maintain constant ambient condition. After the 28 days curing, the boards were stacked in a regulated environment of room temperature at relative humidity of $65 \pm 2 \%$ for 21 days to ensure adequate drying.

Testing of the Board Properties. Each board was cut into $152 \mathrm{~mm} \times 152 \mathrm{~mm} \times 10 \mathrm{~mm}$ for thickness swelling/water absorption test and $194 \mathrm{~mm} \times 50 \mathrm{~mm} \times 10 \mathrm{~mm}$ for modulus of 
rupture/modulus of elasticity tests respectively. Three (3) samples were tested for each of the tests carried out.

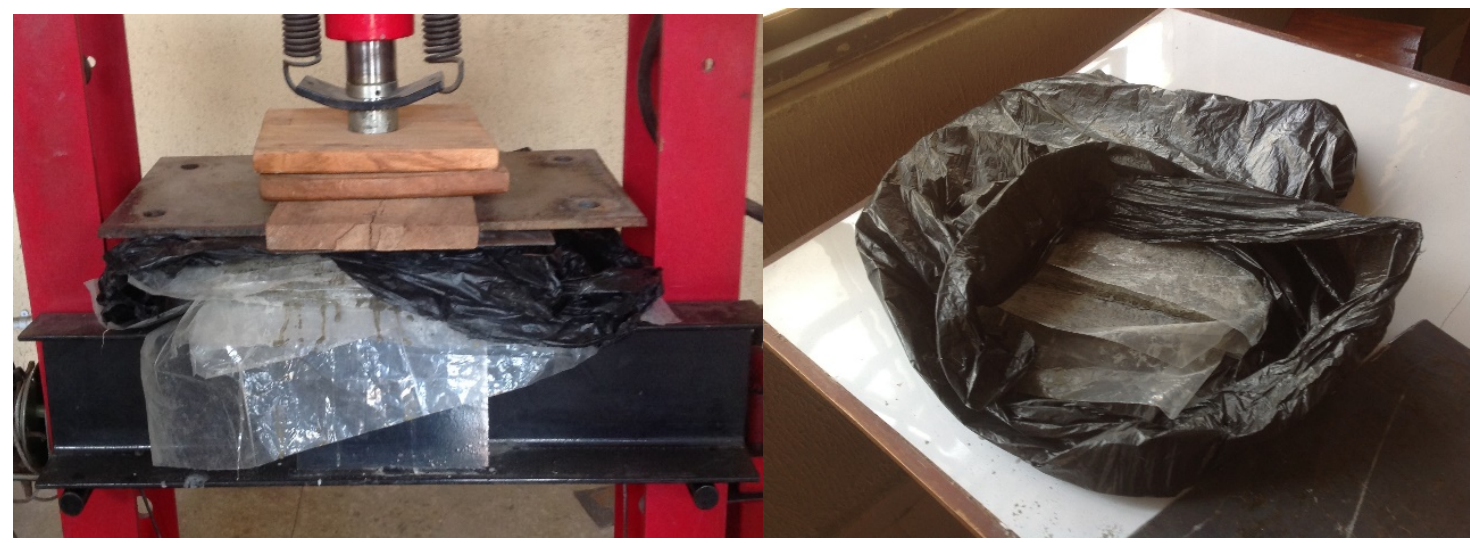

Fig. 3 Hydraulic Jack pressing

Fig. 4 Board curing process

\section{Physical Tests}

Moisture Response Tests. The dry weight (i.e. weight before soaking in water) of the specimens for the water absorption test was recorded as the initial weight and afterwards horizontally arranged in a container with distilled cold water at $20^{\circ} \mathrm{C}$ temperature. The test specimens were left in the water for 1 hour, after which they were dried with a piece of cloth to remove excess water from the soaked specimens before they were finally weighed on a weighing balance. The same steps were carried for the 24 hours test specimens. The readings for water absorption after 1 hour and 24 hours were gotten from the expression:

$$
\text { WA }(\%)=\left(\frac{\text { Final weight }- \text { Initial weight }}{\text { Initial weight }}\right) \times 100
$$

As for the thickness swelling specimens, their initial thicknesses were taken with the aid of a micrometer screw gauge. The boards were soaked in water for 1 hour and 24 hours as that of the water absorption test. After each of the immersion periods, the specimens were removed from water and dried with a piece of cloth before the final thickness was observed. The thickness swelling readings were expressed based on the British code of standards [29] as follows:

$$
\text { TS }(\%)=\left(\frac{\text { Final thickness-Initial thickness }}{\text { Initial thickness }}\right) \times 100
$$

\section{Mechanical Test}

Bending Strength (MOR and MOE). The test specimens were subjected to a load velocity of 556 $\mathrm{N} / \mathrm{sec}$ on the Hounnsfield tensiometer with the support span, in accordance with [30]. Two roller supports were used to support the specimens at the ends. Forward movement of the machine increases the load gradually and continually until the test specimen failed. Failing load was recorded being the force at failure point and it was used to calculate the modulus of rupture (MOR) with the formula:

$$
\mathrm{MOR}=\frac{3 \rho L}{2 b d^{2}}
$$

Where: MOR $=$ Modulus of Rupture, $\rho=$ Failing load $(\mathrm{N}), \mathrm{L}=$ Span between centers of support (mm), $b=$ Width of test specimen $(\mathrm{mm}), d=$ mean thickness of the specimen $(\mathrm{mm})$. 
While the panel's stiffness (MOE) was determined from the bending test performed on each specimen and was calculated using the formula;

$$
\operatorname{MOE}\left(\mathrm{N} / \mathrm{mm}^{2}\right)=\frac{\rho L^{3}}{4 b d^{3} H}
$$

where:

MOE $=$ Modulus of Elasticity; $\rho=$ Failing load $(\mathrm{N}) ; \mathrm{L}=$ Span between centers of support $(\mathrm{mm}) ; \mathrm{b}=$ Width of test specimen $(\mathrm{mm}) ; \mathrm{d}=$ mean thickness of the specimen $(\mathrm{mm}) ; \mathrm{H}=$ Change in deflection $(\mathrm{mm})$.

\section{Results}

Physical Properties. The results of 1 hour and 24 hours water-soaked tests (TS and WA Test) conducted on the experimental boards are as shown in Table 2.

Table 2 Physical Properties of corncob and sawdust ceiling boards

\begin{tabular}{cccccc}
\hline \multirow{2}{*}{$\begin{array}{c}\text { Sample } \\
\text { No }\end{array}$} & $\begin{array}{c}\text { Blended } \\
\text { Proportion } \\
\text { (Ce: Co: S) }\end{array}$ & WA (\%) & TS (\%) & WA (\%) & TS (\%) \\
\cline { 3 - 6 } & & $1 \mathrm{hr}$ & $1 \mathrm{hr}$ & $24 \mathrm{hrs}$ & $24 \mathrm{hrs}$ \\
\hline 1 & $40: 40: 20$ & 21.48 & 5.8 & 26.81 & 3.31 \\
2 & $40: 30: 30$ & 18.81 & 2.61 & 29.32 & 7.21 \\
3 & $40: 20: 40$ & 26.12 & 0.76 & 26.73 & 4.23 \\
4 & $50: 10: 40$ & 13.23 & 0.55 & 27.72 & 2.79 \\
5 & $50: 20: 30$ & 20.99 & 1.22 & 25.81 & 2.84 \\
6 & $50: 25: 25$ & 16.66 & 1.6 & 26.41 & 3.84 \\
7 & $60: 20: 20$ & 16.94 & 0.58 & 24.84 & 6.21 \\
8 & $60: 30: 10$ & 16.55 & 2.61 & 25.27 & 3.06 \\
9 & $60: 10: 30$ & 10.29 & 1.78 & 26.16 & 3.94 \\
\hline
\end{tabular}

Mechanical Properties. Table 3 shows the mean values of MOR and MOE being the mechanical properties considered.

Table 3 Mechanical Properties of corncob and sawdust ceiling boards

\begin{tabular}{cccc}
\hline & \multirow{2}{*}{$\begin{array}{c}\text { Blended } \\
\text { Sample No }\end{array}$} & \multicolumn{2}{c}{ Mechanical Properties } \\
\cline { 3 - 4 } & Proportion & MOR $\left(\mathrm{N} / \mathrm{mm}^{2}\right)$ & MOE $\left(\mathrm{N} / \mathrm{mm}^{2}\right)$ \\
\hline 1 & $40: 40: 20$ & 0.264 & 1627.96 \\
2 & $40: 30: 30$ & 0.66 & 1743.99 \\
3 & $40: 20: 40$ & 1.439 & 3552.65 \\
4 & $50: 10: 40$ & 3.432 & 9351.48 \\
5 & $50: 20: 30$ & 3.234 & 6147.51 \\
6 & $50: 25: 25$ & 2.666 & 5034.73 \\
7 & $60: 20: 20$ & 1.69 & 3383.74 \\
8 & $60: 30: 10$ & 1.212 & 3813.92 \\
9 & $60: 10: 30$ & 2.576 & 4110.1 \\
\hline
\end{tabular}




\section{Discussion}

Physical Properties.

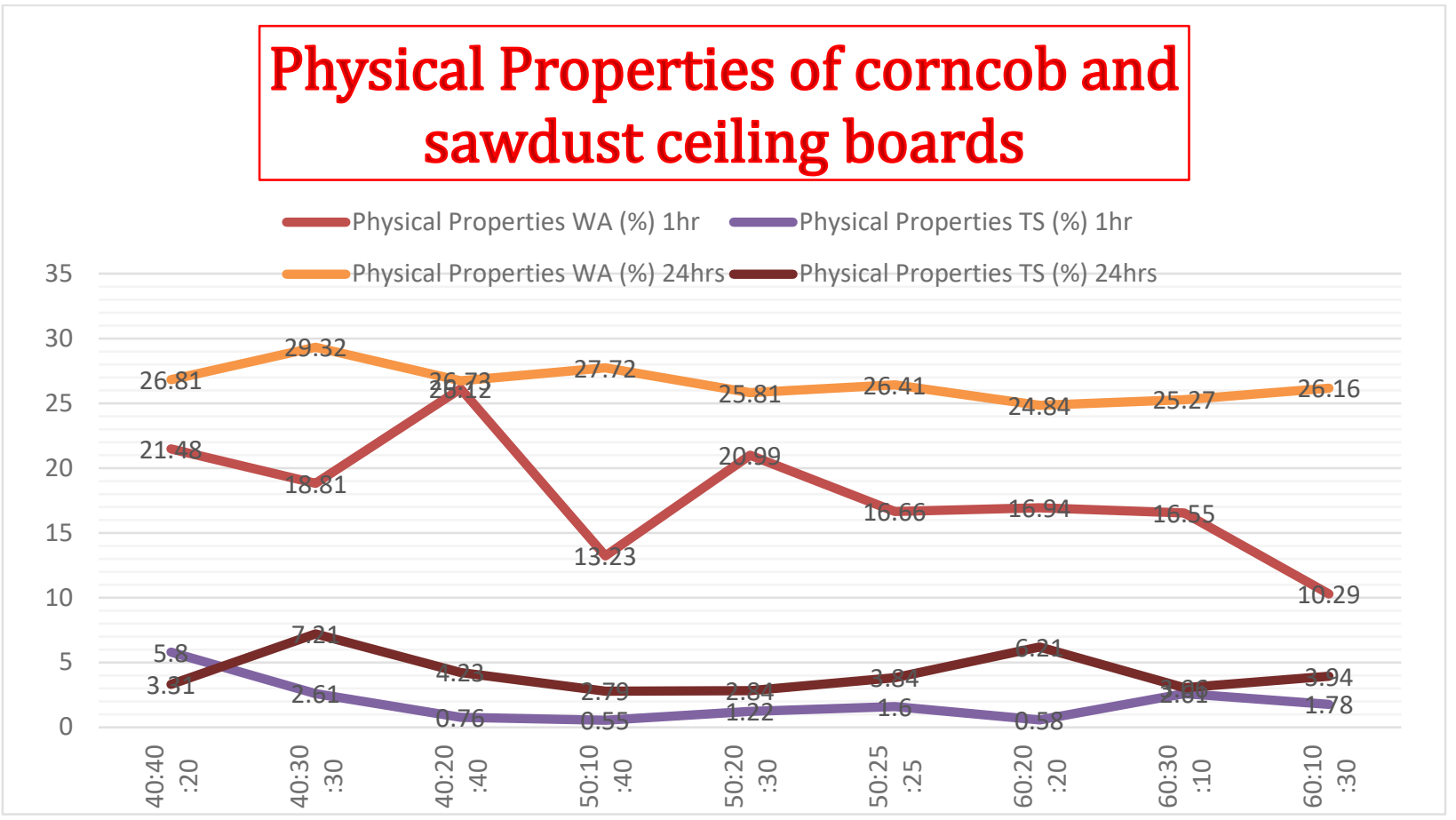

Fig. 5 Water Absorption and Thickness Swelling Values of Ceiling Boards

The mean values obtained from WA in 1 hour of water immersion ranged from $10.29 \%$ to $26.12 \%$ and for 24 hours of water immersion ranged from $24.84 \%$ to $29.32 \%$. These values met property requirements of [31] and suggested that the cement bonded boards produced were dimensionally stable. The results were in agreement with findings from [27, 32, 33] and fig. 5 shows that as the blended proportion of corncobs increases, the WA also increases and vice versa for sawdust proportion, while the binding agent (cement) had significant effect on the properties assessed such that the higher the binding agent, the higher the dimensional stability recorded. This is due to the high absorptive properties of corncob and sawdust.

The mean values obtained from TS in 1 hour of water immersion ranged from $0.55 \%$ to $5.80 \%$ and for 24 hours of water immersion ranged from $2.79 \%$ to $7.21 \%$. These values also met property requirements of [31] which gave expectations up to $35 \%$ and suggested that the cement bonded boards produced were dimensionally stable. Fig. 5 shows that as the blended proportion of corncobs increases, the TS also increases and vice versa for sawdust proportion, while the binding agent (cement) had significant effect on the properties assessed such that the higher the binding agent, the higher the dimensional stability recorded.

The experimental analysis conducted used Completely Randomized Design (CRD). From the results of Analysis of Variance (ANOVA) carried out for the TS and WA, the variables were found to be significantly different at $95 \%$ level of probability as shown in Table 4 and Table 5. 
Table 4 Results of ANOVA for TS at 1 hour and 24 hours water soaking

\begin{tabular}{clccccc}
\hline & \multicolumn{1}{c}{ SV } & DF & SS & MS & Fcal & Sig \\
\hline TS (\%) & Between Group & 8 & 64.925 & 8.116 & 10.856 & 0 \\
for 1 hour & Within Group & 18 & 13.456 & 0.748 & & \\
& Total & 26 & 78.381 & & & \\
& & & & & & \\
TS (\%) & Between Group & 8 & 57.725 & 7.216 & 4.015 & 0.007 \\
for 24 hours & Within Group & 18 & 32.347 & 1.797 & & \\
& Total & 26 & 90.072 & & & \\
\hline
\end{tabular}

* SV-Source of Variation, DF-Degree of Variation, SS-Sum of Squares, MS-Mean Squares, FcalANOVA Value, Sig-Significant Value

Table 5 Results of Analysis of Variance for WA at 1 hour and 24 hours water soaking

\begin{tabular}{|c|c|c|c|c|c|c|}
\hline & $\mathrm{SV}$ & $\mathrm{DF}$ & SS & MS & Fcal & Sig \\
\hline WA (\%) & $\begin{array}{l}\text { Between } \\
\text { Group }\end{array}$ & 8 & 524.157 & 65.52 & 7.677 & 0 \\
\hline for 1 hour & Within Group & 18 & 153.622 & 8.535 & & \\
\hline & Total & 26 & 677.779 & & & \\
\hline
\end{tabular}

$\begin{array}{clccccc}\text { WA (\%) } & \text { Between } & 8 & 43.3 & 5.413 & 6.874 & 0 \\ \text { for 1 hour } & \text { Group } & \text { Within Group } & 18 & 14.172 & 0.787 & \\ & \text { Total } & 26 & 57.472 & & & \\ & & & & & \\ \end{array}$

*SV-Source of Variation, DF-Degree of Variation, SS-Sum of Squares, MS-Mean Squares, FcalANOVA Value, Sig-Significant Value

\section{Mechanical Properties:}

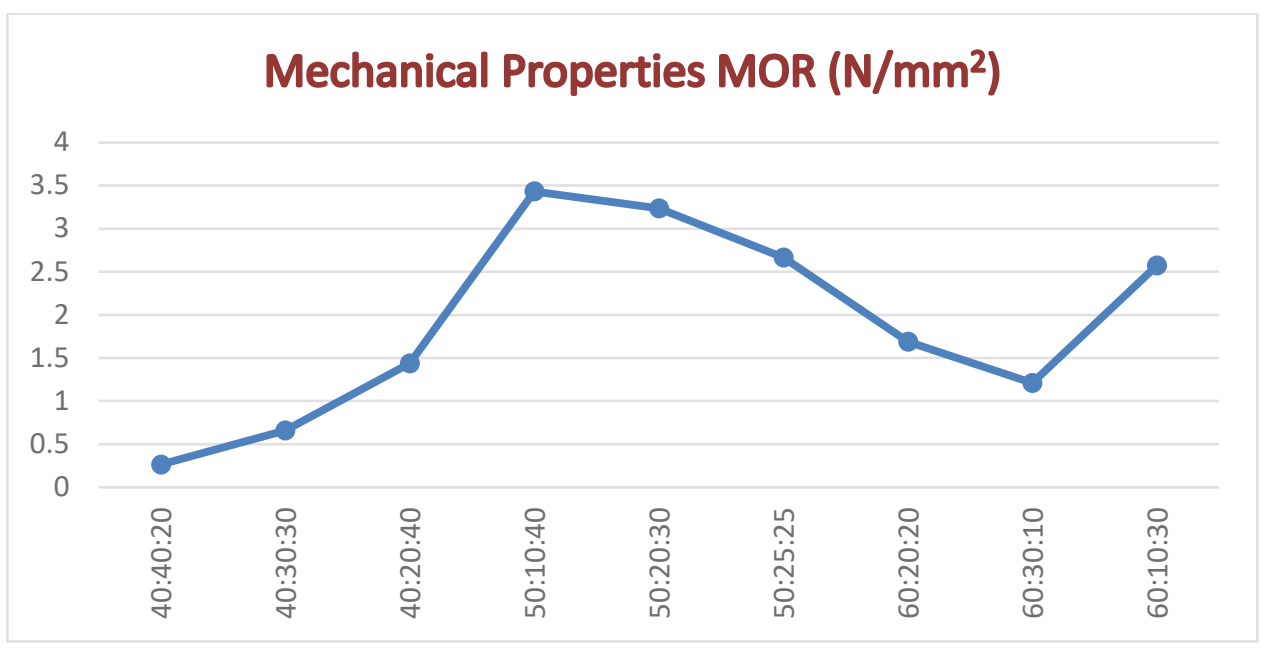

Fig. 6 Modulus of Rupture of Ceiling Boards

From the MOR and MOE results given in table 3, it was deduced that:

The values ranged from $0.264 \mathrm{~N} / \mathrm{mm}^{2}$ to $3.432 \mathrm{~N} / \mathrm{mm}^{2}$ for the MOR and ranged from $1627 \mathrm{~N} / \mathrm{mm}^{2}$ to $9351 \mathrm{~N} / \mathrm{mm}^{2}$ for the MOE. 
The values obtained for the MOR for cement bonded board produced as shown in Fig. 6 reveal that as the corncob is reduced, the values of the MOR increase and as the sawdust proportion is increased, the values of the MOR also increase, while the MOR increases as the binding agent increased from $40 \%$ to $50 \%$ and decreased as the binding agent increased from $50 \%$ to $60 \%$. The American National Standard Institute standard [31] specifies a minimum MOR of $3 \mathrm{~N} / \mathrm{mm}^{2}$ for door core purpose particle boards, only boards 4 and 5 met the requirement.

Table 6 and 7 which shows the ANOVA carried out to test the significant differences among the cement bonded boards produced from different blended proportions reveal that there are significant differences in the MOR and MOE assessed on the different blended proportion of cement, corncob and sawdust. This is an indication that the higher the sawdust, the higher the strength properties, the low amount of corncobs in the blended proportion also has significant effect on the strength properties and dimensional stability of the cement-bonded boards produced.

Table 6 Results of ANOVA for MOR of cement-bonded board produced

\begin{tabular}{clccccc}
\hline & \multicolumn{1}{c}{ SV } & DF & SS & MS & Fcal & Sig \\
\hline \multirow{4}{*}{ MOR } & Between Group & 8 & 30.34 & 3.793 & 14.607 & 0 \\
& Within Group & 18 & 4.674 & 0.26 & & \\
& Total & 26 & 35.014 & & &
\end{tabular}

*SV-Source of Variation, DF-Degree of Variation, SS-Sum of Squares, MS-Mean Squares, FcalANOVA Value, Sig-Significant Value

Table 7 Results of ANOVA for MOE of cement-bonded board produced

\begin{tabular}{clccccc}
\hline & \multicolumn{1}{c}{ SV } & DF & SS & MS & Fcal & Sig \\
\hline \multirow{4}{*}{ MOE } & Between & 8 & $1.00 \mathrm{E}+08$ & 16805051 & 6.865 & 0 \\
& Group & & & & \\
& Within Group & 18 & 44065324 & 2448074 & & \\
& Total & 26 & $2.00 \mathrm{E}+08$ & & & \\
\hline
\end{tabular}

*SV-Source of Variation, DF-Degree of Variation, SS-Sum of Squares, MS-Mean Squares, FcalANOVA Value, Sig-Significant Value

The values obtained for the MOE for cement bonded board produced from different blended proportion as shown in fig. 7 reveals that, MOE is directly proportional to the quantity of sawdust and binding agent while it increases as the quantity of corncob is reduced. This is an indication that the higher the sawdust, the higher the strength properties and the lower the corncobs in the blended proportion also has a significant effect on the properties of the cement-bonded boards produced. The results showed that an increase in the percentage of cement in the boards leads to an increase in the values of the modulus of rupture thus an increase in the strength of the boards. The research also showed that an increase in the percentage of cement in the boards leads to an increase in the values of the modulus of elasticity thus an increase in the strength of the boards. 


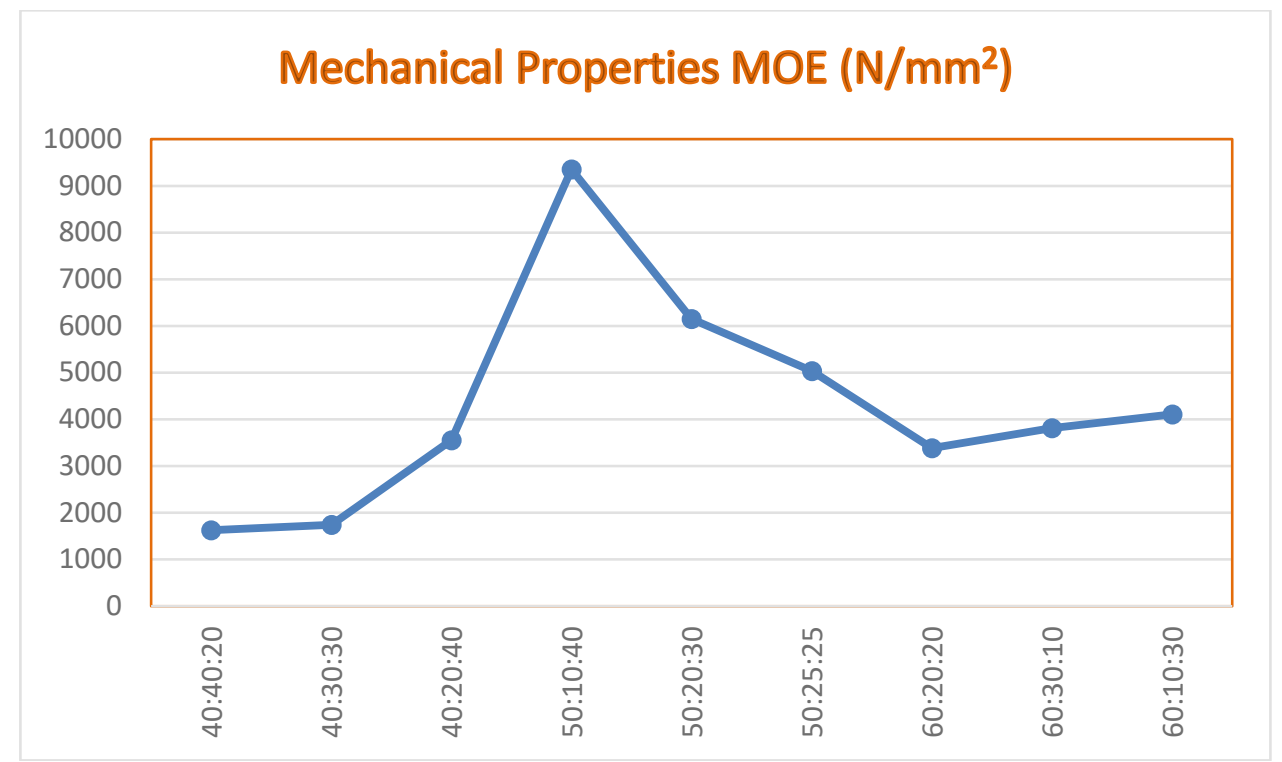

Fig. 7 Modulus of Elasticity of Ceiling Boards

The minimum acceptable value of MOE as specified by the American National Standard Institute standard [31] is $550 \mathrm{~N} / \mathrm{mm}^{2}$, this shows that all the boards produced met the requirement.

It can also be seen that an increase in the percentage of cement in the boards leads to a decrease in the value of water absorption property and this also means an increase in the strength of the boards. Though cement has a huge effect on the properties of the boards produced, sawdust also plays a major role in determining the final strength of the boards and this account for the emergence of the sample with blended proportion of cement, corncob and sawdust in the ratio 50:10:40 as the best board.

\section{Conclusion}

The following conclusions are drawn from this research:

a. Increase in the percentage of cement in the boards leads to decrease in the values of thickness swelling and water absorption properties.

b. Increase in the percentage of cement in the boards leads to increase in the values of MOE and MOR.

The board with cement, corncob and sawdust blending proportion 50:10:40 gives the highest values of MOE and MOR. This indicates the optimum combination of the materials to achieve the highest strength.

From the result of the tests carried out on the cement-bonded board, the boards produced from $10 \%$ of $4 \mathrm{~mm}$ maximum corncob particle size and $40 \%$ sawdust showed the highest potential of use. Therefore, it is recommended that more research into the use of various proportions of other particle sizes of corncob in combination with various proportions of sawdust should be encouraged. Also replacing the binding agent (cement) with polyethylene should be researched into.

\section{Acknowledgement}

The Authors will like to thank Prof. A.A. Raheem (Ladoke Akintola University of Technology, Ogbomoso, Nigeria) for his support towards the success of this research and Mr Aina (Forestry Research Institute of Nigeria) for the facilities provided. 


\section{References}

[1] S. P. Raut, R. V. Ralegaonkar and S. Mandavgane, "Development of sustainable construction material using industrial and agricultural solid waste: a review of waste-create bricks," Construction and Building Materials, pp. 4037-4042, 2011.

[2] S. Odeyemi, M. Akinpelu, O. Atoyebi and R. Yahaya, "Determination of Load Carrying Capacity of Clay Bricks Reinforced With Straw,” Int. J. Sustain. Constr. Eng. Technol., vol. 8, p. 2180-3242, 2017.

[3] O. D. Atoyebi, S. O. Odeyemi, S. A. Bello and C. O. Ogbeifun, "Splitting Tensile Strength Assessment of Lightweight Foamed Concrete Reinforced with Waste Tyre Steel Fiber," International Journal of Civil Engineering and Technology, vol. 9, no. 9, pp. 1129-1137, 2018.

[4] J. Pinto, J. Vieira, H. Pereira, C. Jacinto, P. Vilela and A. Paiva, "Corn cob lightweight concrete for non-structural applications," Construction and Building Material, pp. 346-351, 2012.

[5] X.-y. Zhou, F. Zheng, H.-g. Li and C.-1. Lu, "An environment friendly thermal insulation material from cotton stalks fibers," Energy and Building, vol. 42, pp. 1070-1074, 2010.

[6] N. Chusilp, C. Jaturapitakku and K. Krattikomol, "Utilization of bagasse ash as a pozzolanic material in concrete," Construction Building Material, pp. 3352-3358, 2009

[7] K. Gunasekaran, R. Annadurai and P. S. Kumar, "Plastic shrinkage and deflection characteristics of coconut shell concrete slab," Construction Building Material, pp. 203-207, 2013.

[8] P. Lertsutthiwong, S. Khunthon, K. Siralertmukul, K. Noomun and S. Chandrkrachang, "New insulating particleboards prepared from mixture of solid wastes from tissue paper manufacturing and corn peel," Bioresource Technology, pp. 4841-4845, 2008.

[9] O. Atoyebi and O. Sadiq, "Experimental data on flexural strength of reinforced concrete elements with waste glass particles as partial replacement for fine aggregate," Data in Brief, vol. 18, p. 846-859, 2018.

[10] O. D. Atoyebi, T. F. Awolusi and I. E. Davies, “Artificial neural network evaluation of cementbonded particle board produced from red iron wood (Lophira alata) sawdust and palm kernel shell residues,", Case Studies in Construction Materials, vol. 19, pp. 2340-2343, 2018.

[11] O. M. Sadiq and O. D. Atoyebi, "Flexural strength determination of reinforced concrete elements with waste glass aspartialreplacementfor fine aggregate,", NSE Tech. Trans. Journal of Nigerian Society of Engineers, vol. 49, p. 74-81, 2015.

[12] V. M. Mangesh, V. R. Rahul and A. M. Sachin, "Application of agro-waste for sustainable construction materials : A review," Construction and Building Materials, vol. 38, pp. 872-878, 2013.

[13] O. Atoyebi, S. Odeyemi and J. Orama, "Experimental data on the splitting tensile strength of bamboo reinforced lateritic concrete using different culm sizes,," Data in Brief, vol. 20, pp. 1960-1964, 2018.

[14] N. Soon-Ching and L. Kaw-Sai, "Thermal conductivity of newspaper sandwiched aerated lightweight concrete panel," Energy and Building, p. 2452-2456, 2010.

[15] C. Hasse, M. Grenet, A. Bontemps, R. Dendievel and H. Sallée, “Realization, test and modeling of honeycomb wallboards containing a phase change material," Energy and Buildings, pp. 232238, 2011.

[16] N. Quaranta, M. Caligaris, H. López, M. Unsen, N. Lalla, M. Franzoy, M. Carrasco, J.Cotroni and M. Avenda., "Addition of polymeric wastes as pore formers in ceramic lightweight bricks.," Transactions on Ecology and the Environment, pp. 447-458, 2010. 
[17] D. Adesanya and A. Raheem, "A study of the workability and compressive strength characteristics of corn cob ash blended cement concrete," Construction and Building Material, pp. 311-317, 2009.

[18] D. Adesanya and A. Raheem, "Development of Corn Cob Ash Blended Cement," Construction and Building Materials, pp. 347-352, 2009.

[19] D. Adesanya, "The effects of thermal conductivity and chemical attack on corn cob ash blended cement.," The Professional Builder, pp. 3-10, 2001.

[20] J. Coutinho, "The Combined benefits of CPF and Rice Husk Ash in improving the durability of Concrete Structures.," Cement and Concrete Composites, pp. 51-59, 2003.

[21] M. Nehdi, J. Duquette and A. El-Damatty, "Performance of Rice Husk Ash produced using a new Technology as a Mineral Admixture in Concrete," Cement and Concrete Research, pp. 1203-1210, 2003.

[22] D. Bui, J. Hu and P. Stroeven, "Particle size effect on the strength of Rice Husk Ash Blended Gap-Graded Portland Cement Concrete.," Cement and Concrete Composites, pp. 357-366, 2005.

[23] U. Tomas and G. Jr, " Investigation on the Use of Pleko Ceiling Board for Heat Insulator and Sound Proofing Material Applications," International Journal of Advanced Science and Technology, pp. 23-32, 2014.

[24] P. Anabela, S. Pereira, A. Sá, D. Cruz, H. Varum and J. Pinto, "A contribution to the thermal insulation performance characterization of corncob particleboards.," Energy and Building, pp. 274-279, 2012.

[25] P. Soroushian and M. Hassan, "Evaluation of cement-bonded strawboard against alternative cement-based siding products," Construction and Building Materials, pp. 77-82, 2012.

[26] S. R. Karade, "Cement-bonded composites from lignocellulosic wastes," Construction and Building Materials, vol. 24, no. 8, pp. 1323-1330, 2010.

[27] A.Ashori, T. Tabarsa and S. Sepahvand, "Cement-bonded composite boards made from poplar strands," Construction and Building Materials, vol. 26, pp. 131-134, 2012.

[28] FAO, "FAOSTAT," 7 October 2016. [Online]. Available: http://faostat3.fao.org/search/ World\%20maize\%20producers/E.

[29] BS EN 317:1993, "Particleboards and fiberboards. Determination of swelling in thickness after immersion into water," British Standard Institution, London, 1993.

[30] BS EN 310:1993, "Wood-based panels. Determination of modulus of elasticity in bending and of bending strength," British Standard Institution, London, 1993.

[31] A.A208-1-1999, American National Standard Institute. American National Standard -Particleboard, Gaithersburg: Composite Panel Association, 1999.

[32] A.Olorunnisola and O. Adefisan, "Trial production and testing of cement-bonded particleboard from rattan furniture waste," Wood Fiber Science, vol. 34, no. 1, p. 116-124, 2002.

[33] Olorunnisola, "Strength and water absorption characteristics of cement bonded particleboard produced from coconut husk.," Journal of Civil Engineering Research and Practices, vol. 3, no. 1, p. 41-49, 2006. 